\title{
Improving Engineering Students' Ability in Writing Descriptive Text Using GBA
}

\author{
Sri Hastuti \\ Department of English, Politeknik Negeri Bandung \\ Bandung, Indonesia \\ E-mail: sri.hastuti@polban.ac.id
}

\begin{abstract}
Writing is one of the English skills needed by engineering students to express their knowledge and skill relating to their major. Based on the researcher's teaching experience, students still have low ability in writing. In this research, the researcher made an effort to improve their descriptive writing text in an engineering context. The aim was to increase their ability to make descriptive text using Genre Based Approach. The research was carried out in the Road and Bridge Planning Study Program in the Civil Engineering Department of a Polytechnic in Indonesia. The sample included the students of the study program. The design of the research was the Pre Test-Post Test Design. The result shows that the students' writing ability can be increased by applying the GBA teaching procedure with adjustment to their major and level of English capability. This strategy can be used as an alternative to improve students' ability to make descriptive texts in an engineering context.
\end{abstract}

Keywords: descriptive text, engineering context, genre-based approach.

\section{INTRODUCTION}

In a globalization era, making texts is one of the necessities that university level students should have. Nowadays, in which technology grows very fast, the demands from industry also increase so fast while there are so many job applicants. Students have harder challenges to compete with other competitors to pursue their intended career. This is a crucial issue that must be solved in the midst of their tight learning schedule. In the tight competition among job applicants, there must be a way to prepare students to face this condition. There should be an effort to help students to be able to perform their capabilities in their best to gain the best career they want. One of the ways to show their capabilities is by expressing it through texts, either written or spoken.

There are several text types that should be mastered by Polban students, which are in line with their major. For engineering students, one of them is a descriptive text type. Why they should be able to make descriptive text is that they have to be able to describe a certain object, for example, a certain bridge, a road, in English. Thus, whenever they 
are asked to describe a certain object, hopefully, they can do it correctly and fluently. This is the reason why this research was conducted.

The researcher recognizes that Polban students, in this case, engineering students, face a relatively tight schedule. They have to follow and pass a number of lectures of their study program and lectures of general subjects, including English in six or eight semesters. For studying English, generally, they have only two hours a week for two semesters, yet they need it for enhancing their study and for their career in the near future. In this tight schedule, the researcher tried an effort to help the students increase their ability to make the text. She had to teach them in an effective way to increase their ability to make this type of text. For this effort, the researcher applied Genre Based Approach (GBA) that is an approach to teach writing according to each type of text. The application of GBA was aimed to examine whether the ability of engineering students to make a descriptive text can be increased or not.

\section{LITERATURE FRAMEWORK}

\section{Previous research}

Efforts to improve students' writing ability have been done from an early age. Relating to the topic, a research entitled Improving students' achievement on writing descriptive text through think pair share was done by Tiur Asih Siburian (2013). This study was about increasing the ability of Junior High School students in Prapat North Sumatera to make a paragraph of descriptive text type using the TPS method. TPS stands for Think Pair Share method is one of the methods to teach writing.

Besides that, Ratna Prasasti Suminar and Giska Putri (2015) had done research entitled "The Effectiveness of TTW (Think-Talk-Write) Strategy in Teaching Writing Descriptive Text. TTW (Think Talk-Write). The study was to examine the effectiveness of the strategy to teach descriptive text in Unswagati Cirebon. The following research entitled Reading and writing descriptive and persuasive texts was conducted by Patricia L Carrel and Ulla, Connor (1991). This study was about the relationship between reading and writing of both persuasive and descriptive texts. Those research used different methods, were conducted in different sites and fields of study. 
This research applied the Genre Based Approach in a specific field of study, and the students used in the sample were Polytechnic students. The field of study is civil engineering, and the location of the study is in Politeknik Negeri Bandung.

\section{Genre-based approach}

Genre-based approach (GBA) is chosen as the researcher assumed that it is suitable for engineering students. In line with this Yang (2012:188) stated that the Genrebased approach can be a motivational tool for English learning in the ESP classroom. Polytechnic graduates mostly look for a job after they finish their study, thus giving lectures that correlate with their major will be felt useful by the students. Yang also states that GBA is suitable to be applied in both Polytechnic and traditional Universities as their students' majors are mostly professional-or occupational oriented.

GBA has three main features that lead and complement students to produce appropriate technical text. They are context, schematic structure, and grammar. According to Macken-Horarik (2002:19), there is a relationship between language use and its social environment. Furthermore, Halliday (1985:12) represents this immediate social environment in terms of the context of a situation which comprises field (subject matter), tenor (role), and mode (channel of communication).

These three variables of the context of the situation determine a text (Halliday, 1985: 24-26, Eggins, 1994:52-53). Those three variables have to be taken into consideration when making a text. If it is in the civil engineering field, for example, to write a text about a suspension bridge, thus the text might be focused on describing the features it has. In regard to tenor, the writer should consider who will be the readers. Meanwhile, mode relates to the form of text which will be presented either in written or oral form. Those variables will determine the choice of a topic relating to the study program, structures, and words to convey the message appropriately in a suitable text type or genre. 


\section{Descriptive genre (text type)}

Civil engineering students, as a sample of this research, are expected to be able to express their ability, knowledge, skill, and expertise in a text either in written or spoken form. In this research, the students are asked to make a text about a specific civil engineering object relating to their major. Thus the researcher used descriptive genre, as this genre can be used for describing things (Gerot and Wignell, 1994:208-209, Meer, 2016, Djuharie 2007:24). For this research, the researcher adopted the model text proposed by Linda Gerot and Peter Wignell (1994:208-209) with some modifications.

The descriptive genre model by Linda Gerot and Peter Wignell (1994:208-209) has features as follows.

a. Social function of this genre: to describe a particular person, place or thing.

b. Generic structure of this genre: identification: identifies phenomenon to be described

c. Description: describes parts, qualities, characteristics

d. Significant Lexicogrammatical features: focus on specific participants

e. Use of attributes and identifying processes

f. Frequent use of epithets and classifiers in nominal groups

g. Use of Simple Present Tense.

While Djuharie (2007:24) explains that description text has the following structure:

a. identification which introduces the subject or thing to be described

b. description which informs the characteristics of the subject or the thing.

Description text usually uses certain language:

a. specific noun, for example, Pasupati Bridge, Erasmuss bridge, Jagorawi toll road, etc.

b. simple Present Tense

c. detailed noun phrase, for example ..sophisticated modern camera, extremely beautiful bridge, etc.

The model used by the researcher after the modification is described under the following part, methodology 


\section{METHOD}

GBA, which has specific features, is considered to be appropriate for the teaching of making text in engineering students. The simple and explicit components are easy to be followed by the students. For this research, the research question is, "Can the ability of engineering students to write make a descriptive text be increased by applying the Genre Based Approach?" To answer the question, the following research design was applied.

\section{Research Design}

The research was carried out in the Road and Bridge Planning Study Program of Civil Engineering Department, Bandung State Polytechnic, Bandung. The sample consisted of 28 students in the study program. The design of the research is Pre-TestPost-Test Design (Hatch and Lazaraton, 1991:20). The formula is T1 X T2. T1 is PreTest, $\mathrm{X}$ is Treatment, and T2 is Post-Test. The data were collected from the Pre-test and Post Test, whereas the treatment was executed by teaching the students. Figure 1, as follows, is a diagram of carrying out the research:

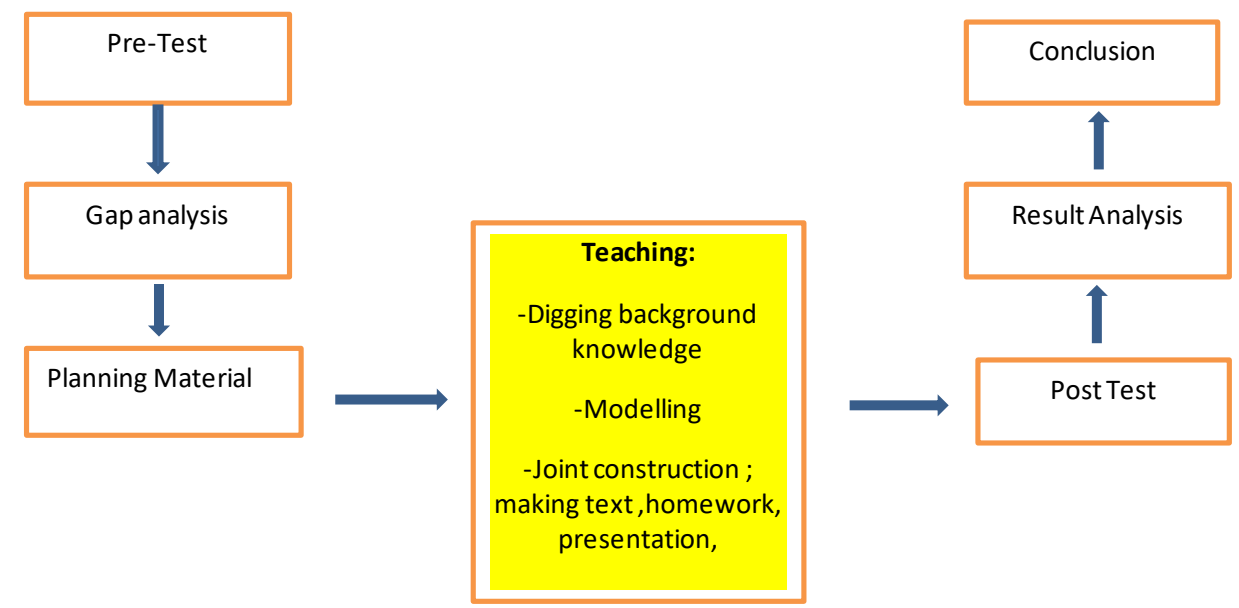

Figure 1. Research Flow Diagram 
At the beginning of the research, the students were given a Pre-Test. They were asked to make a descriptive text. At that time, the lecturer did not give any information about descriptive text to them. This Pre-test was only to know their basic capability about making descriptive text. The texts that they made then were collected to be analyzed relating to the gap.

After checking the students 'texts of the Pre-Test, the gap was found. All of them did not know the Schematic Structure of descriptive text. Relating to registers, all of the students have already used terms relating to their major. As for the grammar, only a few of them made mistakes. On the other hand, most students have already been relatively fluent in making sentences with registers relating to their major. They made an essay, not a paragraph anymore.

In designing teaching material, the lecturer used a model of the descriptive text's general structure (Gerot and Wignell, 1994:208-209). As the English ability of the students is not in the basic stage anymore, the lecturer improves the model into an essay model. The lecturer also taught them how to make an essay. Thus the lecturer prepares descriptive text in the form of an essay. Afterward, the students were taught with the prepared material.

Actually, the overall planning and teaching activity adapt the principles of the genre-based teaching procedure proposed by Macken-Horarik (2002:27-32). The procedure comprises four elements, i.e., planning (constructing how to make a descriptive text as the proposed way to be used), teaching process (the steps of teaching), reflection (the understanding of the students towards the materials), and assessment strategies (how to assess their competence). 
Thus firstly, before the teaching process, the researcher planned and made the model text to be taught. The model text followed the features proposed by Linda Gerot and Peter Wignell (1994:208-209) comprising the generic structure: identification, description, significant Lexicogrammatical features with some necessary modifications. Secondly, the teaching process followed four of five teaching stages of the GBA teaching cycle (Feez and Joyce, 1998a:65-68). Those are building up knowledge of the field, modelling, joint construction, and independent construction. In building up knowledge of the field, the researcher digged the background knowledge and then gave knowledge and explanation about the descriptive text. In modelling, the researcher gave a model of descriptive text and explained each feature in more detail. In joint construction, the students were divided into groups and were asked to make a descriptive text together. In that stage, the researcher went around and helped each group in case they needed help during the making of the text. This part was the stage when the exercise was given to the students in groups. The researcher also gave the students homework in a group at home.

Thirdly, for reflection, the researcher asked a question to the students about the parts that they have understood and those they have not understood. The researcher also gave more explanations relating to mistakes that were found in their homework. Fourthly, for the assessment strategies, the researcher gave an individual test as Post Test. The result was analyzed (shown in the diagram). The score of which was compared to the score of the pre-test given before the treatment (the teaching process). The result of the comparison will show whether the students' ability can be increased or not. The last step is the conclusion in which the researcher found and learned a number of things. This experience can make her the following teaching better.

\section{Process of how to increase students ability}

The effort to increase students' ability to make descriptive text underwent several steps that adopted the principles of GBA teaching. The application of the teaching was as follows. 


\section{Doing Pre-Test}

In giving Pre-Test, the researcher asked the students to make a descriptive text about the topic of an object relating to their study program. At that time, the researcher told the students not to look at any notes, dictionaries, and other resources. The researcher gave 40 minutes to do a Pre-Test. Collecting the papers of the Pre-Test, the researcher checked the papers. She found that all of the students made mistakes in Schematic Structure and grammar, but not in registers. Most of the students made texts of $3 / 4$-one page long. Only three of the students made half page long. The researcher noted these gaps. They did not know about the Schematic Structure and Grammatical mistakes, specifically in False Present Tense, Subject Verb-Agreement, and Passive Voice. The researcher took notes of these things to be considered in preparing material to be taught.

\section{Planning}

Based on the fact that most of the students were already able to make quite long description, the researcher made model text by modifying the model text proposed by Gerot and Wignel (1994:208). The model is mentioned in Table 1: 
Table 1. The model used for this research

\begin{tabular}{|c|c|c|c|c|c|}
\hline \multicolumn{3}{|c|}{ Gerot and Wignel (1994:208) } & \multicolumn{3}{|c|}{ The model used for this research } \\
\hline $\begin{array}{l}\text { Social } \\
\text { Function: }\end{array}$ & \multicolumn{2}{|c|}{ to describe person, place or thing } & $\begin{array}{l}\text { Social } \\
\text { Function : }\end{array}$ & \multicolumn{2}{|c|}{$\begin{array}{l}\text { to describe thing (civil } \\
\text { engineering object) }\end{array}$} \\
\hline \multirow[t]{2}{*}{$\begin{array}{l}\text { Generic } \\
\text { Structure : }\end{array}$} & Identification : & $\begin{array}{l}\text { Identifies } \\
\text { phenomenon } \\
\text { to be described }\end{array}$ & $\begin{array}{l}\text { Generic } \\
\text { Structure : }\end{array}$ & $\begin{array}{l}\text { Identification } \\
:\end{array}$ & $\begin{array}{l}\text { Identifies civil } \\
\text { engineering } \\
\text { object } \\
\text { to be described }\end{array}$ \\
\hline & Description : & $\begin{array}{l}\text { Describes } \\
\text { parts, qualities, } \\
\text { characteristics }\end{array}$ & & Description : & $\begin{array}{l}\text { Describes parts, } \\
\text { qualities, } \\
\text { characteristics } \\
\text { (The length can } \\
\text { be extended as } \\
\text { needed) }\end{array}$ \\
\hline $\begin{array}{l}\text { Significant } \\
\text { lexicogrammat } \\
\text { ical features : }\end{array}$ & \multicolumn{2}{|c|}{$\begin{array}{l}\text { - Focus on specific Participant } \\
\text { - Use of Attributive and } \\
\text { Identifying Precesses } \\
\text { - Frequent use of Epithets and } \\
\text { Classifiers in nominal groups } \\
\text { - Use of Simple Present Tense }\end{array}$} & $\begin{array}{l}\text { Significant } \\
\text { lexicogram } \\
\text { matical } \\
\text { features : }\end{array}$ & \multicolumn{2}{|c|}{$\begin{array}{l}\text { - Focus on specific Participant } \\
\text { - Use of Attributive and } \\
\text { Identifying Precesses } \\
\text { - Frequent use of Epithets and } \\
\text { Classifiers in nominal } \\
\text { groups } \\
\text { - Use of Simple Present Tense } \\
\text { - Use of Simple Past Tense } \\
\text { (for example to describe } \\
\text { when a bridge was opened } \\
\text { for public). } \\
\text { - Passive voice }\end{array}$} \\
\hline
\end{tabular}

Besides preparing the model, the researcher also prepared the material of Present Tense and Passive voice to be explained.

\section{Teaching Process}

The next step was teaching the materials to the students. On this occasion, the researcher explained every aspect of descriptive text and the use of descriptive text specifically for describing an object in the civil engineering field. In addition to that, the researcher also clarified the use of Present Tense and Passive Voice. She drilled more on the students who made mistakes in Pre-Test 
Afterward, the researcher asked students to make the descriptive text about one civil engineering object in groups. In doing this work, the students are allowed to see the information from the internet. They were told what information to be taken from the internet for example, kind of bridge, location, when it was inaugurated, the length of the bridge, what areas which are connected by the bridge, parts of a bridge, materials of the bridge parts, the design including its beauty, etc. They were asked to retell the information using their own sentences. They were also asked to write down the resources or websites where they took the information from. In this group work, it seems that they enjoy the activity of making the text together. They discussed and shared their knowledge to arrange sentences and to use appropriate terms. As the lecture time was over, they were asked to finish the work at home and to send the work via email.

In the following week, they were asked to make a presentation about objects using the text they made. Before the presentation, the researcher had already checked their work. In this presentation activity, the students also enjoy the activity and look relaxed. They asked and answered questions enjoyable. In this opportunity, the researcher was also able to correct the wrong pronunciation of some terms made by several students. After each presentation, the researcher showed the mistakes, either the ones are written or those spoken in the presentation. After all, the presentation had already been done; the students were asked to study descriptive text. They were told that they were going to have Post-Test. In the Post-Test, they would be allowed to take notes of points of a topic that they want to describe, similar to the notes they used in group work.

\section{Giving Post-Test}

In the following week, the researcher gave Post-Test. In doing the Post-Test, the students were not allowed to use any resources except the points of an object to be described prepared beforehand. At that time, the researcher monitored the students cautiously. Finally, the papers of the Post-Test were collected to be checked and to be analyzed. 


\section{Data analysis}

In more detail, the data were analyzed using a paired t-test (Coolidge, 2000:160163). The purpose of using a t-test is to examine whether or not there are significant differences between the two groups' means. Whereas the objective of this analysis is to know the students' performance before treatment (Pre Test scores, X1) and after the treatment (Post Test scores, X2).

\section{RESULTS AND DISCUSSION}

After the application of teaching descriptive texts using GBA, there were scores of Pre-Test and Post-Test to be analyzed. To analyze the data, a paired t-test (Coolidge, 2000:160-163) was used. This t-test was to examine whether the difference between the mean of Pre-Test and that of Post-Test is significant or not. While the aim of doing this analysis is was to know whether the students' performances increased after having treatment by comparing Pre Test scores, X1 (before the treatment), and Post Test scores, X2 (after the treatment). For this matter, the following statistical hypothesis was made:

$\mathrm{H}_{\mathrm{o}}=$ There are no differences between scores of Pre Test and scores of Post Test

$\mathrm{H}_{\mathrm{o}}=\mu^{1}=\mu^{2}$

$\mathrm{H}_{\mathrm{a}}=$ There are no differences between scores of Pre Test and scores of Post Test

$\mathrm{H}_{\mathrm{a}}=\mu^{1} \neq \mu^{2}$

After conducting the Pre-Test, Treatment, and Post-Test, the researcher got the findings as described in the following Table 2 and Figure 2. 
Table 2 Result of Pre Test and Post Test

\begin{tabular}{|c|c|c|}
\hline No of Student & PreTest & Post Test \\
\hline 1 & 70 & 85 \\
\hline 2 & 64 & 75 \\
\hline 3 & 50 & 90 \\
\hline 4 & 60 & 85 \\
\hline 5 & 70 & 80 \\
\hline 6 & 63 & 85 \\
\hline 7 & 56 & 85 \\
\hline 8 & 56 & 90 \\
\hline 9 & 43 & 75 \\
\hline 10 & 70 & 85 \\
\hline 11 & 56 & 80 \\
\hline 12 & 60 & 87 \\
\hline 13 & 63 & 95 \\
\hline 14 & 63 & 85 \\
\hline 15 & 70 & 90 \\
\hline 16 & 65 & 85 \\
\hline 17 & 70 & 85 \\
\hline 18 & 55 & 80 \\
\hline 19 & 62 & 75 \\
\hline 20 & 60 & 75 \\
\hline 21 & 65 & 80 \\
\hline 22 & 57 & 76 \\
\hline 23 & 40 & 80 \\
\hline 24 & 58 & 70 \\
\hline 25 & 58 & 76 \\
\hline 26 & 70 & 85 \\
\hline 27 & 70 & 90 \\
\hline 28 & 63 & 75 \\
\hline Average & 60.96 & 82.29 \\
\hline $\begin{array}{l}\text { Deviation } \\
\text { Standard }\end{array}$ & $S x^{2}=7.84$ & $S x^{1}=6.12$ \\
\hline$S\left(x^{2}-x^{1}\right)$ & \multicolumn{2}{|l|}{1.88} \\
\hline
\end{tabular}




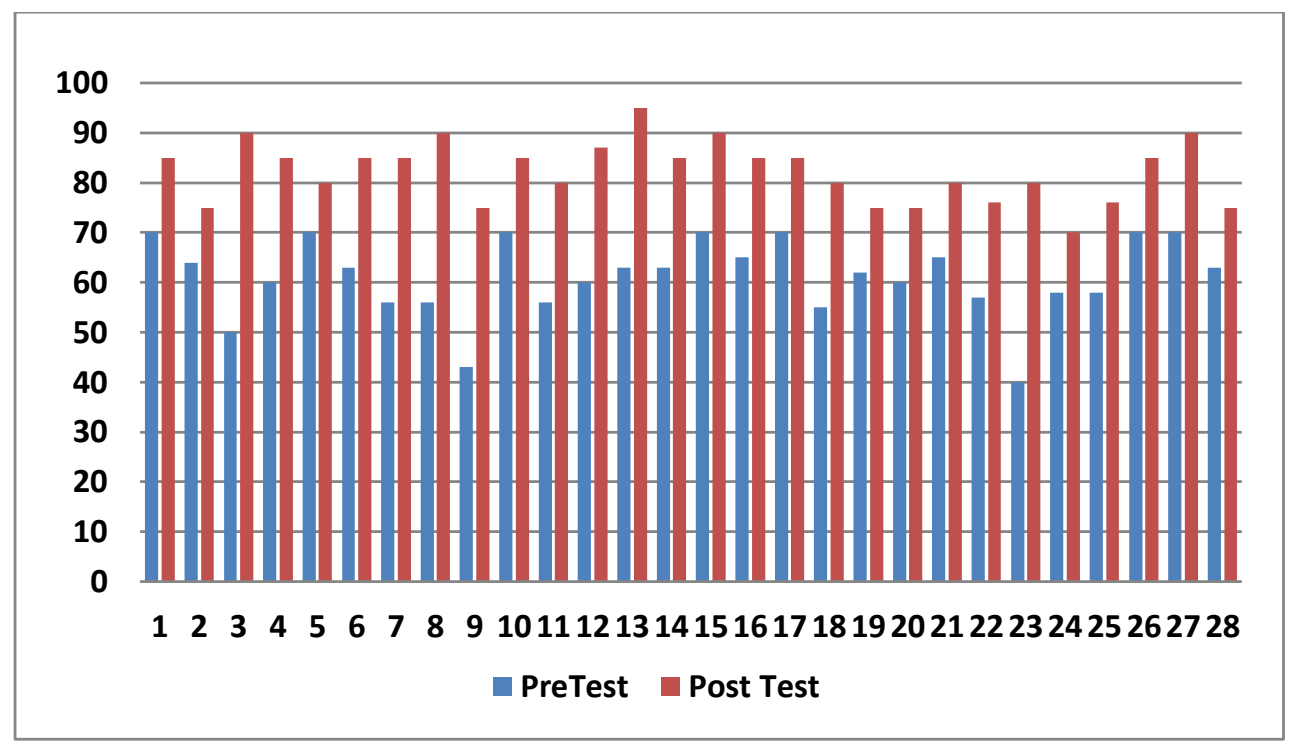

Figure 2. Graph of Pre Test and Post Test

From Table 2, it is known that the average score of Pre-Test was only 60.96, and it increased after the treatment to 82.29. Having calculated the data above, then $t$ the researcher focused on calculating the following formula: is calculated as follows:

$$
\begin{aligned}
t & =\left(x^{2}-x^{1}\right) / S\left(x^{2}-x^{1}\right) \\
& =(82,29-60,96) /(1,88) \\
& =11.35
\end{aligned}
$$

while $\mathrm{t}$-table is \pm 2.021 for $\alpha=5 \%$. Therefore, Ho is rejected, and H1 is accepted. It means that there are differences between the pre-test $\left(\mathrm{x}^{1}\right)$ and the post-test $\left(\mathrm{x}^{2}\right)$, which means that the application of GBA can increase the students' ability. So, we can see that the average score of the students has significantly increased from 60.96 in Pre-Test to 82.29 in PostTest.

Table 2 also shows that the Deviation Standard score has decreased from 7.84 to 6.12. This decrease of the Deviation Standard score from 7.84 to 6.12 shows that the GBA application has increased the ability of the students of all competence levels, High Achievers, The Middle Achievers, and The Low Achievers, as also shown in Figure 2. The gap between each student score and the average score becomes smaller. 


\section{DISCUSSION}

In the beginning, the researcher gave Pre-Test; she found that all of the students did not know what descriptive text is. Most of the students said they studied the descriptive text in senior high school, but they have already forgotten. They said they also studied other types of text, such as narrative, report, argumentative, etc.

What the researcher found in the Pre Test are as follows. Relating to the schematic structure, all of them made mistakes, and the texts they made did not follow the schematic structure of descriptive text type. They just described without paying attention to the steps or structure of the text. Thus their description is not systematic and several of the students mixed up with the report genre. They made texts about a bridge in general. They didn't write about a specific bridge.

On the other hand, relating to registers, they were already able to use terms of civil engineering area. The number of terms used by them is various. A number of students used many varieties of terms while there were still several students using a limited number of civil engineering terms. It is interpreted that they have known terms of civil engineering as they were already in the third semester of the second year of study. They have studied lectures about civil engineering, even though they were delivered in Bahasa Indonesia (Indonesian language).

As to lexicogrammar, many students used Present Tense while the other students still used many verbs in Past Tense form inappropriately. A number of students were able to use Present Tense correctly as what is demanded in writing descriptive text. Thus, there was not a thorough improvement of all students relating to lexicogrammar

The result of the Post Test showed the following. Firstly, relating to Schematic Structure, all of the students did not make any mistakes. They followed the steps taught that is: Identification, description, description, description until finished. Furthermore, they also followed the characteristics of descriptive text, such as describing a specific bridge, specific road, etc. They did not mix up with the report genre anymore. From these findings, the researcher interpreted that the Schematic Structure of the descriptive text of the genre-based approach was not difficult for them to follow; therefore, they did not make a mistake. 
As to registers, they used a sufficient number of Civil engineering terms for bridges and roads. Relating to the topics, five students wrote about roads in Indonesia, one student wrote about a road in Italy, one student wrote about a street in Indonesia. The other 21 students wrote about bridges in Indonesia. They used the terms correctly. From this finding, the researcher interpreted that most of the students chose the topics which are available in Indonesia. This might make them easier to transfer what they might have seen relating to bridges or roads in Indonesia into their thought, then into constructing words and sentences.

In regard to lexicogrammar, there were eight students who made grammatical mistakes. Five of the students made False Present Tense and False Subject + Verb Agreement in one or two of their sentences. Three of them made several kinds of grammatical mistakes. They are False Present Tense, False Subject + Verb Agreement, False Passive Voice, Past Tense. The mistakes they made are as follows: Suramadu bridge is consists of three parts (example of False Present Tense), Indonesia get the request from. (False Subject + Verb Agreement), The surface of Cipali make from concrete pavement (False Passive Voice). There is one student used a number of Past Tense to describe a bridge which happened in the past. While descriptive text is text which describes facts in present time. Apart from those things, the other students did not make mistakes relating to the use of Present Tense which should be mostly used in descriptive text. Based on the findings, it can be interpreted that Present Tense, Subject-Verb Agreement and Passive voice have not been mastered by the students who made mistakes.

\section{CONCLUSION}

After conducting this research, the researcher comes to the conclusion that GBA can increase the students' competence in making the technical text of descriptive text type by making a significant increase. The process of how to teach descriptive text provided a significant contribution to the increase in the students' ability. All the students from the high achievers till the low achievers can make descriptive texts. Group work brought a positive impact on the process of increasing the students'ability. In group work, students were able to share their knowledge and skill freely and happily to make the descriptive 
text about an engineering object that they chose themselves. Thus, in Post-Test, each student was able to make the text using additional knowledge taken from group work.

The Schematic Structure of the text helped guide the students to make a description of an object systematically. For university level students, the model of descriptive text has to be modified and elaborated to adjust to the things the students should describe. For example, to make a descriptive text about Suramadu Bridge in Indonesia, there will be a number of components to describe. Thus, the descriptive text will contain more than two or three paragraphs. The descriptive texts made by the students were one page long on average.

Relating to registers, as the sample contained civil engineering students of the third semester, there were already a number of civil engineering terms they were able to use. In other words, the length and the complexity of descriptive text will also depend on the vocabulary the students have already learned previously in their field of study. 27 out of 28 students did not make any mistakes relating to the use of Schematic Structure and registers.

On the other hand, all of the students still made mistakes in regard to grammar, even though they made only a few mistakes. There were two kinds of grammatical mistakes they tended to make, and they were difficult to eliminate. They are False Present Tense, False Subject-Verb Agreement. There should be further studies to examine why this happens and how to solve this problem. Furthermore, there were still several students who made mistakes in making Present Passive Voice that also needs to be given special attention.

This research made the students confident and creative in making a text about an object they also study in their major. What they study in the English language correlates with what they study in their major. In the research, the students used civil engineering topic, which certainly will be beneficial for their future. Therefore, they were courageous and curious about making the text.

On the other hand, the researcher, as a lecturer, took a number of benefits too. A teacher has to consider the condition of every sample, which might not be the same every year. The researcher can prepare better materials relating to the making of descriptive text in accordance with students' English competence. Modification of the basic model should 
be made relating to the students' English competence. For this sample, more varieties of vocabulary regarding registers and the more varieties regarding kinds of sentences can be applied. In making descriptive text, Past Tense could be used in one or two sentences, for example, to describe the date when a bridge was opened to be used by the public. The creativity of the lecturer is badly demanded to challenge the students to make good descriptive text in accordance with their needs relating to their major.

Having done this research, the researcher recommends that this teaching strategy can be used as an alternative to increase engineering students' ability in making descriptive texts in an engineering context.

\section{REFERENCES}

Carrel, Patricia L, and Connor, Ulla (1991). Reading and writing descriptive and persuasive texts. The Modern Language Journal. Accessed on 21 May 2019

Coolidge, F.L. (2002). Statistics: A Gentle Introduction. London: SAGE Publications.

Djuharie, Otong Setiawan (2007). Genre dilengkapi 700 soal uji pemahaman. Bandung: Yrama Widya

Eggins, S. (1994). An Introduction to Systemic Functional Linguistic. New York: Continuum.

Gerot, L. and Wignel, P. (1994). Making sense of functional grammar. Cammeray NSW: Gerd Stabler.

Feez, S. and Joyce, H. (1998). Writing Skills: Narrative and Non-Fiction Text Types, Australia: Phoenix Education.

Hatch, E. and Farhady, H. (1982) Research Design and Statistics for Applied Linguistics. USA: Newbury House Publishers, Inc.

Hatch, E. and Lazaraton, A. (1991). The Research Manual: Design and Statistics for Applied Linguistics. New York: Newbury House Publishers

Halliday, M.A.K., and Hasan, R. (1985). Language, context, and text: Aspects of Language in a social-semiotic perspective. Victoria: Deakin University

Macken-Horarik, M. (2002). "Something to shoot for: A Systemic Functional Approach to Teaching Genre in Secondary School Science.” In Johns, A.M.2002 (Ed.) Genre in the Classroom, 13-42. London: Lawrence Erlbaum Associates.

Siburian, Tiur Asih (2013). Improving Students' Achievement on Writing Descriptive Text through Think Pair Share the International Journal of Language Learning and Applied Linguistics World (IJLLALW) Accessed on 21 May 2019 
Suminar, Ratna Prasasti, and Putri, Giska (2015). The Effectiveness of TTW (Think-TalkWrite) Strategy in Teaching Writing Descriptive Text. TTW (Think-Talk-Write). PERSPEKTIVE Journal of English Language and Learning. Accessed on 22 May 2019

Yang, Wen-hsien (2012) Evaluating the Effectiveness of Genre-Based Instruction: A Writing Course of English for Hospitality and Tourism Asian EFL Journal, 14(4), 174-193. 